\title{
Assessment of Nurse Managers' Needs for Managerial Innovation Skills
}

\author{
Maha Muhamad Rashed, Neamat Mohamed Elsayed, Samah Mohamed Abdullah, \& Soad Ahmad Ghallab, \\ Assistant Lecturer in Nursing Administration, Faculty of Nursing, Assiut University, Egypt. \\ Professor of Nursing Administration, Faculty of Nursing, Damanhour University, Egypt. \\ Professor of Nursing Administration, Faculty of Nursing, Assiut University, Egypt. \\ Assistant Professor of Nursing Administration, Faculty of Nursing, Assiut University, Egypt.
}

\begin{abstract}
Needs assessment defined as an assessment of which employees need training or development and what type of skills or knowledge they need to acquire. Innovation is the cornerstone of both clinical practice and health care organizational success. Managerial innovation in health service delivery and organization has become a central issue. Aim: to identify needs of nurse managers for managerial innovation skills at Assuit University Hospitals. Research design: descriptive resaerch design. Study subjects: (107) all nurse managers worked at Assuit University Hospitals. Setting: this study was done at Assuit University Hospitals (Main hospital, Pediatric hospital and Women health center). Study tools: managerial innovation needs assessment sheet. Results: there were core skills for managerial innovation as $(69.2 \%)$ for asking probing questions to gather a large body of information, and (71.6\%) for look for and obtain new responsibilities and (72.9\%) for keeps an organized schedule, and provides workers with reminder for critical tasks. Conclusion: Nurse managers were need different skills required for managerial innovation. Recommendations: Provide training program for nurse managers about innovation. Provide climate and environment to serve inspiration of innovative ideas. Give reward and motivate by incentives to share innovation. Provide training program for new concepts of nursing management.
\end{abstract}

\section{Keywords. Managerial Innovation, Needs Assessment \& Nurse Managers.}

\section{Introduction}

Nursing has a social mandate to address the health needs of society with individuals and organizations commetted to meeting these needs. Multiple strategies are used in nursing to achieve this goal such as the development of clinical knowledge and dissemination of these knowledge within nursing and to greater society. Nursing is a practice discipline. which have the goal of manipulating phenomenon in a purposful way (Rhberta \& Hally, 2006).

Managerial innovation continues to attract enormous interest among management scholars Seeman \& Rizo, (2009) stated that, increasingly hear the word innovation used in managerial, technical, administrative and work environment. While O'Grady, (2007) suggested that innovation is the cornerstone of both clinical practice and health care organizational success. Innovation in health service delivery and organization has become a central issue. Innovation is defined as seeing the familiar things from point unfamiliar then develop this seeing to become idea and develop the idea to become design then become innovation capable to implementing and using. The first step in staff development is needs assessment for an educational program (Sullivan \& Decker, 2009, Amodeo et al., 2009). Failure to assess these needs accurately can result in welldeveloped but potentially irrelevant offering for learners and the organizations (Yoder wise, 2009) Needs assessment defined as an assessment of which employees need training or development and what type of skills or knowledge they need to acquire (George \& Jones 2008). Moreover McCawley, (2009), added that, needs assessment is a systematic approach to studying the state of knowledge, ability, interest, or attitude of a defined audience or group involving a particular subject.

Types of needs assessment:

Needs assessment could be categorized as 1) blind needs identified by supervisor-administrator, head nurses and coordinators. These are needs of which the staff are unaware, 2) shared needs identified both by the staff and supervisors, 3) hidden needs which are the needs reported by nurses or needs assessment tools which were not known or identified by supervisors and un discovered needs, all other needs not identified cited by Ghallab, (1994) \& Naswall et al., (2008) classified needs assessment as: 1) real needs is the discrepancy that actually exists and can be met by learning experience, 2) felt needs is something a person feels he needs to know it may or may not be a real learning needs expressed needs,3) needs expressed by action, normative needs: what health professionals define as a need.

Components of Needs Assessment

According to Barkley, (2009) stated that "keep in mind the overarching goal of your needs assessment should be provide insight into the needs, objectives, 
and interests. Needs assessment should also provide additional important context that is helpful in designing programs and support services for the group Nies \& McEwen, (2011) illustrate steps in needs assessment process as the following: Identify aggregate for assessment, identify required information, select the method of data gathering, develop questionnaire or interview questions, develop procedures for data collection, train data collectors, arrange for a sample representative of the aggregate, conduct needs assessment, tabulate and analyze data, identify needs suggested by data and develop an action plan.

Methods for identifying learning needs

Direct and indirect assessments

A direct needs assessment is accomplished through formal research that gathers data from clientele. The direct assessment will result in data that is more specific to the needs of individuals, and it can be quantitative in terms of probability and confidence. Direct assessment should be conducted periodically for major program efforts. An indirect approach uses secondary data or asks surrogates (advisors) for their opinions about priority needs and issues. Direct need assessment provide information by means of a straightforward solicitation of educational needs. Example of direct techniques include interview, focus group, and written questionnaires (Alaoutinen et al., 2012).

An indirect assessment can be conducted at any time when an advisory committee is meeting and does not require the same level of investment in the design, implementation, and analysis. However, even for a non-formal assessment, if the results are to be credible, procedures must be followed, and findings must be carefully documented. Indirect methods of needs assessment use analyses of the work situation and various hospital records to yield information related to nurses' educational needs. Examples of indirect techniques include observation, listening, and review of hospital documents (Neraagja, 2011).

Comprehensive needs assessment research helps document actual problems and deficiencies. With the needs assessment in hand, an educator can 1) verify and describe the current situation, 2) explain how the program will address that need, and 3) describe the expected impacts of the program (i.e., build a logic model).

Questionnaire; are a popular form of need assessment because of their low cost and ease of administration. Questionnaires can address a wide array of topics, assess diverse educational needs, and sample a large population. Each learner answers questions from a prepared list in order to provide information about learning needs (Mahmoud, \& Ajmal Khan, 2007)
Individual learning plan: Each learner identifies individual learning goals and a plan for attaining them. The plan can include reasons for learning, times she or he prefers to study, methods to be used, etc (Abouelenein, 2016).

In other words, self-reporting is representative of an individual's beliefs or experiences that reflect the individual's situational knowledge. The individual's response to the situation, whether behavioral or written, reflects the information the individual wishes to reveal (Irbha et al., 2016).Incident report :These reports are reports of employee behavior that are out of the ordinary, in either a positive or a negative direction and are recorded on a form or an index cared with space for four items: name of employee, data and time of incident, a brief description of what occurred, and the nurse manager's comments on what transpired (Sullivan and Decker, 2009)

\section{Observation}

"Seeing is believing" as the old saying goes: direct observation is generally provides more powerful evidence than that which can be obtained from secondary sources. Going to the field to observe the subject first hand can be an effective way of gathering evidence the results of field observation recorded through photos or videos can also helpful and may have a powerful impact on the reader if used in the evaluation record. Direct observation is essential part of data gathering and assessing needs (Treasury Board of Canada Secretariat, 2011).

\section{Subjects \& Methods}

This study aimed to assess of nurse managers' needs for managerial innovation at Assiut University Hospitals

The methodology pursued in the conduction of the study will be described under four designs, namely technical, operational, administrative, and statistical designs.

Technical design: This design includes; study design, setting, subjects, and tools of data collection.

Research design: Descriptive design was used.

Setting of the study: This study was carried out in three University hospitals at upper Egypt, including hospitals involved in this study, hospital number one the main Assiut University hospital, the hospital number two, Pediatric hospital and hospital number three was Woman health hospital. 


\section{Subjects of the study}

Subject of the study: Included all nurse managers (first line) of the mentioned hospitals

\begin{tabular}{|l|c|}
\hline \multicolumn{1}{|c|}{ Hospital } & Nurse manager number \\
\hline Hospital No. (1) & 77 \\
\hline Hospital No. (2) & 22 \\
\hline Hospital No. (3) & 8 \\
\hline
\end{tabular}

Tools of the study

The tools of this study will include:

Needs assessment tool for managerial innovation: This sheet developed by David, (2006). The tool contains 98 statements divided into these categories, Learning:9 items, Creativity and imagination:14 items, Energy level and motivation: 9 items, Commitment and sense of ownership:14 items, Mission and vision: 5 items, Communication, interpersonal skills, and emotional intelligence: 18 items, Leading groups and teams: 9 items, Understanding the external environment: 4 items, Role identity, power and politics:10 items and management and delegation: 6 items.

\section{Scoring system}

The rating scale of the needs assessment tool will be used as ( 1 means expert, 2 means core, 3 means supplementary but quarterly, 4 means supplementary but yearly, and 5 means remove)

\section{Operational design}

This design explains the steps of actual implementation of the study, including validity, the pilot study and the field work.

\section{Validity}

The content validity of the needs assessment sheet was assessed to check the relevance, coverage, and clarity of the questions by the jury were composed of (5) professors and assistant professors in nursing administration and community health nursing.

\section{Pilot study}

A pilot study was carried out to test accessibility of study sample, time consuming of the study tool. It was carried on a group of sixteen head nurses before embarking on the field work to find out the difficulties present in questions in order to modify or clarify them, or to omit or add certain questions, and to estimate time needed to fill the forms. Also, the pilot helped to determine the organizational and administrative procedures needed for the study, and detect constraints that may arise and how to deal with them. Data collection from the pilot study were analyzed, reviewed and used in making necessary modification prior to the final application of the study tools. The duration of this phase took about two months, from January 2015 to march.
The reliability of the study tool clarified in this table

\begin{tabular}{|l|c|}
\hline \multicolumn{1}{|c|}{ Variables } & $\begin{array}{c}\text { Cronbach } \\
\text { alpha }\end{array}$ \\
\hline Learning & 0.706 \\
\hline Creativity and imagination & 0.833 \\
\hline Empowerment and motivation, & 0.606 \\
\hline $\begin{array}{l}\text { Commitment and sense of } \\
\text { ownership, }\end{array}$ & 0.872 \\
\hline Mission and vision, & 0.497 \\
\hline Communication, & 0.880 \\
\hline Building teams, the external & 0.911 \\
\hline $\begin{array}{l}\text { Understanding } \\
\text { environment, }\end{array}$ & 0.824 \\
\hline Organizational identity, & 0.805 \\
\hline Management & 0.649 \\
\hline
\end{tabular}

\section{Field work}

Assessing needs to identify needs of nurse managers about managerial innovative skills. After ensuring the clarity of the tools the actual data collection from head nurses from April to June 2015.

\section{Ethical consideration}

Oral agreement was taken from the participants of the study

II. Administrative design: Requesting permission from relevant authorities: permission to collect data from Assiut University Hospitals.

\section{Statistical Design:}

Data entry was done using excel computer software program, while statistical analysis was done using SPSS version 16 statistical software packages. Data were presented using descriptive statistics in the form of frequencies and percentages for qualitative variables. 


\section{Results}

Table (1): General characteristics of nurse managers (No. 107).

\begin{tabular}{|c|c|c|}
\hline Characteristics & No. $(n=107)$ & $\%$ \\
\hline \multicolumn{3}{|l|}{ Place of work } \\
\hline Main Assuit University Hospital & 77 & 72.0 \\
\hline Pediatric University Hospital & 22 & 20.6 \\
\hline Women Health University Hospital & 8 & 7.5 \\
\hline \multicolumn{3}{|l|}{ Sex } \\
\hline Male & 8 & 7.5 \\
\hline Female & 99 & 92.5 \\
\hline \multicolumn{3}{|l|}{ Age } \\
\hline$<30$ years & 22 & 20.6 \\
\hline $30-<35$ years & 18 & 16.8 \\
\hline $35-<40$ years & 39 & 36.4 \\
\hline$\geq 40$ years & 28 & 26.2 \\
\hline \multicolumn{3}{|l|}{ Level of education } \\
\hline Diploma of Nursing & 9 & 8.4 \\
\hline Technical Institute of Nursing & 1 & 0.9 \\
\hline Bachelor of Nursing & 97 & 90.7 \\
\hline \multicolumn{3}{|l|}{ Marital status } \\
\hline Married & 87 & 81.3 \\
\hline Single & 19 & 17.8 \\
\hline Divorced & 1 & 0.9 \\
\hline \multicolumn{3}{|l|}{ Years of experience } \\
\hline$<10$ years & 42 & 39.3 \\
\hline $10-<20$ years & 44 & 41.1 \\
\hline$\geq 20$ years & 21 & 19.6 \\
\hline \multicolumn{3}{|c|}{ Attending training courses related to managerial innovation } \\
\hline Yes & 0 & 0.0 \\
\hline No & 107 & 100.0 \\
\hline
\end{tabular}

Table (2): Needs assessment of nurse managers related to learning (No. 107).

\begin{tabular}{|c|c|c|c|c|c|c|c|c|c|c|}
\hline \multirow{2}{*}{ Description } & \multicolumn{2}{|c|}{ Remove } & \multicolumn{2}{|c|}{$\begin{array}{l}\text { Suppl. } \\
\text { yearly }\end{array}$} & \multicolumn{2}{|c|}{$\begin{array}{c}\text { Suppl. } \\
\text { quarterly }\end{array}$} & \multicolumn{2}{|c|}{ Core } & \multicolumn{2}{|c|}{ Expert } \\
\hline & No & $\%$ & No. & $\%$ & No & $\%$ & No & $\%$ & No & $\%$ \\
\hline $\begin{array}{l}\text { Refreshes core knowledge of the profession to } \\
\text { stay sharp. }\end{array}$ & 0 & 0.0 & 3 & 2.8 & 19 & 17.8 & 73 & 68.2 & 12 & 11.2 \\
\hline $\begin{array}{l}\text { Seeks out new approaches, tools, methods, and } \\
\text { technologies in own field of expertise by } \\
\text { reading, talking to others inside and outside the } \\
\text { organization, }\end{array}$ & 0 & 0.0 & 3 & 2.8 & 19 & 17.8 & 68 & 63.6 & 17 & 15.9 \\
\hline $\begin{array}{ll}\text { Attending seminars/conferences. anticipates } \\
\text { applicability to the hospital }\end{array}$ & 9 & 8.4 & 9 & 8.4 & 13 & 12.1 & 53 & 49.5 & 23 & 21.5 \\
\hline $\begin{array}{l}\text { Applying technical and professional } \\
\text { innovations. Uses knowledge of technical/ } \\
\text { professional developments to influence the } \\
\text { strategic direction. }\end{array}$ & 0 & 0.0 & 0 & 0.0 & 6 & 5.6 & 70 & 65.4 & 31 & 29.0 \\
\hline $\begin{array}{l}\text { Identifies strengths, weaknesses, opportunities } \\
\text { and threats of their discipline by performing in- } \\
\text { depth needs analysis. }\end{array}$ & 0 & 0.0 & 0 & 0.0 & 12 & 11.2 & 57 & 53.3 & 38 & 35.5 \\
\hline
\end{tabular}




\begin{tabular}{|c|c|c|c|c|c|c|c|c|c|c|}
\hline \multirow{2}{*}{ Description } & \multicolumn{2}{|c|}{ Remove } & \multicolumn{2}{|c|}{$\begin{array}{l}\text { Suppl. } \\
\text { yearly }\end{array}$} & \multicolumn{2}{|c|}{$\begin{array}{c}\text { Suppl. } \\
\text { quarterly }\end{array}$} & \multicolumn{2}{|c|}{ Core } & \multicolumn{2}{|c|}{ Expert } \\
\hline & No & $\%$ & No. & $\%$ & No & $\%$ & No & $\%$ & No & $\%$ \\
\hline $\begin{array}{l}\text { Has a complete understanding of and is capable } \\
\text { of expressing the strengths, weaknesses, } \\
\text { opportunities, and threats of their discipline. }\end{array}$ & 0 & 0.0 & 6 & 5.6 & 3 & 2.8 & 66 & 61.7 & 32 & 29.9 \\
\hline $\begin{array}{l}\text { Asks probing questions in order to gather a } \\
\text { large body of information }\end{array}$ & 6 & 5.6 & 3 & 2.8 & 20 & 18.7 & 74 & 69.2 & 4 & 3.7 \\
\hline $\begin{array}{l}\text { Understands and believes that new lessons can } \\
\text { be learned every day and seeks to find each } \\
\text { day's lesson. }\end{array}$ & 6 & 5.6 & 9 & 8.4 & 44 & 41.1 & 46 & 43.0 & 2 & 1.9 \\
\hline $\begin{array}{l}\text { Searches academic and professional article data } \\
\text { bases on people, products, companies, }\end{array}$ & 0 & 0.0 & 15 & 14.0 & 33 & 30.8 & 34 & 31.8 & 25 & 23.4 \\
\hline $\begin{array}{l}\text { Routinely provides training and/or assistance to } \\
\text { less-experienced staff. Educates decision- } \\
\text { makers. }\end{array}$ & 0 & 0.0 & 3 & 2.8 & 33 & 30.8 & 48 & 44.9 & 23 & 21.5 \\
\hline $\begin{array}{l}\text { Seeks and engages in appropriate formal higher } \\
\text { education opportunities. }\end{array}$ & 9 & 8.4 & 3 & 2.8 & 15 & 14.0 & 43 & 40.2 & 37 & 34.6 \\
\hline $\begin{array}{l}\text { Encourages peers and subordinates to seek } \\
\text { advanced degrees where applicable. }\end{array}$ & 3 & 2.8 & 3 & 2.8 & 15 & 14.0 & 47 & 43.9 & 39 & 36.4 \\
\hline
\end{tabular}

Table (3) Needs assessment of nurse mangers related to creativity and imagination (No. 107).

\begin{tabular}{|c|c|c|c|c|c|c|c|c|c|c|}
\hline \multirow[t]{2}{*}{ Description } & \multicolumn{2}{|c|}{ Remove } & \multicolumn{2}{|c|}{$\begin{array}{l}\text { Suppl. } \\
\text { yearly }\end{array}$} & \multicolumn{2}{|c|}{\begin{tabular}{|c|} 
Suppl. \\
quarterly \\
\end{tabular}} & \multicolumn{2}{|c|}{ Core } & \multicolumn{2}{|c|}{ Expert } \\
\hline & No & $\%$ & No & $\%$ & No. & $\%$ & No & $\%$ & No & $\%$ \\
\hline $\begin{array}{l}\text { Seeks to anticipate and identify problems before } \\
\text { they arise so that they do not become } \\
\text { insurmountable }\end{array}$ & 0 & 0.0 & 0 & 0.0 & 16 & 15.0 & 54 & 50.5 & 37 & 34.6 \\
\hline $\begin{array}{l}\text { Demonstrates independent creativity to develop new } \\
\text { approaches/systems that go beyond one's } \\
\text { experience or do not exist. }\end{array}$ & 3 & 2.8 & 6 & 5.6 & 9 & 8.4 & 39 & 36.4 & 50 & 46.7 \\
\hline $\begin{array}{l}\text { Understands that new ideas come from all levels of } \\
\text { staff not just at the senior level. }\end{array}$ & 0 & 0.0 & 3 & 2.8 & 32 & 29.9 & 58 & 54.2 & 14 & 13.1 \\
\hline Seek new ideas from subordinate & 6 & 5.6 & 0 & 0.0 & 36 & 33.6 & 52 & 48.6 & 13 & 12.1 \\
\hline $\begin{array}{l}\text { Is willing to make mistakes on the path to a good } \\
\text { idea. Is not afraid to make a less than stellar } \\
\text { suggestion. }\end{array}$ & 6 & 5.6 & 0 & 0.0 & 32 & 29.9 & 47 & 43.9 & 22 & 20.6 \\
\hline $\begin{array}{l}\text { Understands complex problems, identifies critical } \\
\text { issues, and generates varied solutions to problems }\end{array}$ & 6 & 5.6 & 3 & 2.8 & 37 & 34.6 & 32 & 29.9 & 29 & 27.1 \\
\hline Accept failure to reach new ideas & 7 & 6.5 & 0 & 0.0 & 21 & 19.6 & 62 & 57.9 & 17 & 15.9 \\
\hline Not afraid from my work to be excellent. & 12 & 11.2 & 3 & 2.8 & 6 & 5.6 & 47 & 43.9 & 39 & 36.4 \\
\hline Understand complex problems. & 3 & 2.8 & 3 & 2.8 & 6 & 5.6 & 64 & 59.8 & 31 & 29.0 \\
\hline 10-Find new solutions. & 0 & 0.0 & 0 & 0.0 & 11 & 10.3 & 68 & 63.6 & 28 & 26.2 \\
\hline Apply critical thinking to solve problem. & 0 & 0.0 & 0 & 0.0 & 3 & 2.8 & 63 & 58.9 & 41 & 38.3 \\
\hline $\begin{array}{l}\text { Identifies similar situations in other organizations or } \\
\text { disciplines. Applies ideas to the company's field of } \\
\text { expertise. }\end{array}$ & 3 & 2.8 & 0 & 0.0 & 1 & 0.9 & 55 & 51.4 & 48 & 44.9 \\
\hline $\begin{array}{l}\text { Facilitates the creative processes of peers and } \\
\text { subordinates. }\end{array}$ & 0 & 0.0 & 0 & 0.0 & 18 & 16.8 & 45 & 42.1 & 44 & 41.1 \\
\hline Records ideas, uses and applies results of session. & 0 & 0.0 & 0 & 0.0 & 27 & 25.2 & 38 & 35.5 & 42 & 39.3 \\
\hline Create scenario to learn subordinates. & 3 & 2.8 & 6 & 5.6 & 22 & 20.6 & 33 & 30.8 & 43 & 40.2 \\
\hline Observes the behavior of participants interprets and & 9 & 8.4 & 0 & 0.0 & 24 & 22.4 & 41 & 38.3 & 33 & 30.8 \\
\hline
\end{tabular}




\begin{tabular}{|c|c|c|c|c|c|c|c|c|c|c|}
\hline \multirow{2}{*}{ Description } & \multicolumn{2}{|c|}{ Remove } & \multicolumn{2}{|c|}{$\begin{array}{l}\text { Suppl. } \\
\text { yearly }\end{array}$} & \multicolumn{2}{|c|}{\begin{tabular}{|c|} 
Suppl. \\
quarterly
\end{tabular}} & \multicolumn{2}{|c|}{ Core } & \multicolumn{2}{|c|}{ Expert } \\
\hline & No & $\%$ & No & $\%$ & No. & $\%$ & No & $\%$ & No & $\%$ \\
\hline \multicolumn{11}{|l|}{ discusses results. } \\
\hline $\begin{array}{l}\text { Adapts to change, shifts thought processes easily, } \\
\text { and conforms to environmental changes. }\end{array}$ & 3 & 2.8 & 0 & 0.0 & 25 & 23.4 & 60 & 56.1 & 19 & 17.8 \\
\hline 18- Advocates change in a positive manner. & 0 & 0.0 & 3 & 2.8 & 24 & 22.4 & 62 & 57.9 & 18 & 16.8 \\
\hline $\begin{array}{l}\text { Fosters an environment where team members feel } \\
\text { free to experiment with new ideas. }\end{array}$ & 0 & 0.0 & 0 & 0.0 & 28 & 26.2 & 60 & 56.1 & 19 & 17.8 \\
\hline $\begin{array}{l}\text { Sits quietly in a pleasant area and thinks about } \\
\text { anything. }\end{array}$ & 0 & 0.0 & 0 & 0.0 & 30 & 28.0 & 56 & 52.3 & 21 & 19.6 \\
\hline $\begin{array}{l}\text { Leverages and exploits the utility of uncertain } \\
\text { situations. }\end{array}$ & 0 & 0.0 & 6 & 5.6 & 36 & 33.6 & 31 & 29.0 & 34 & 31.8 \\
\hline
\end{tabular}

Table (4): Needs assessment of nurse mangers related to energy level and motivation (No. 107).

\begin{tabular}{|c|c|c|c|c|c|c|c|c|c|c|}
\hline \multirow[t]{2}{*}{ Description } & \multicolumn{2}{|c|}{ Remove } & \multicolumn{2}{|c|}{$\begin{array}{l}\text { Suppl. } \\
\text { yearly }\end{array}$} & \multicolumn{2}{|c|}{$\begin{array}{c}\text { Suppl. } \\
\text { quarterly }\end{array}$} & \multicolumn{2}{|c|}{ Core } & \multicolumn{2}{|c|}{ Expert } \\
\hline & No. & $\%$ & No. & $\%$ & No. & $\%$ & No. & $\%$ & No. & $\%$ \\
\hline $\begin{array}{l}\text { Works to find the motivators of peers and } \\
\text { subordinates. }\end{array}$ & 0 & 0.0 & 0 & 0.0 & 33 & 30.8 & 51 & 47.7 & 23 & 21.5 \\
\hline Offers the encouragement and direction needed. & 0 & 0.0 & 0 & 0.0 & 27 & 25.2 & 60 & 56.1 & 20 & 18.7 \\
\hline Helps people feel positive about adversity. & 0 & 0.0 & 6 & 5.6 & 18 & 16.8 & 54 & 50.5 & 29 & 27.1 \\
\hline $\begin{array}{l}\text { Balances work responsibilities and personal } \\
\text { duties. }\end{array}$ & 3 & 2.8 & 0 & 0.0 & 12 & 11.2 & 50 & 46.7 & 42 & 39.3 \\
\hline Seeks appropriate ways to let go of anxiety. & 3 & 2.8 & 0 & 0.0 & 12 & 11.2 & 58 & 54.2 & 34 & 31.8 \\
\hline $\begin{array}{l}\text { Exhibits boundless enthusiasm for the task and } \\
\text { outcome. }\end{array}$ & 3 & 2.8 & 0 & 0.0 & 12 & 11.2 & 48 & 44.9 & 44 & 41.1 \\
\hline Seeks excellence in results. & 3 & 2.8 & 9 & 8.4 & 12 & 11.2 & 58 & 54.2 & 25 & 23.4 \\
\hline Takes on the toughest assignments. & 3 & 2.8 & 0 & 0.0 & 9 & 8.4 & 43 & 40.2 & 52 & 48.6 \\
\hline Likes to do stimulating work. & 0 & 0.0 & 3 & 2.8 & 9 & 8.4 & 68 & 63.6 & 27 & 25.2 \\
\hline Looks for and obtains new responsibilities. & 0 & 0.0 & 3 & 2.8 & 3 & 2.8 & 83 & 77.6 & 18 & 16.8 \\
\hline 11- Understands timelines and priorities. & 0 & 0.0 & 3 & 2.8 & 13 & 12.1 & 74 & 69.2 & 17 & 15.9 \\
\hline $\begin{array}{l}\text { Appropriately raises the energy level in the group } \\
\text { through example. }\end{array}$ & 0 & 0.0 & 3 & 2.8 & 9 & 8.4 & 66 & 61.7 & 29 & 27.1 \\
\hline $\begin{array}{l}\text {-Possesses an inner sense of obligation to tasks of } \\
\text { high value. }\end{array}$ & 0 & 0.0 & 6 & 5.6 & 12 & 11.2 & 69 & 64.5 & 20 & 18.7 \\
\hline $\begin{array}{l}\text { Motivated by positive feedback and either } \\
\text { external or internal encouragement. }\end{array}$ & 3 & 2.8 & 3 & 2.8 & 4 & 3.7 & 76 & 71.0 & 21 & 19.6 \\
\hline $\begin{array}{l}\text { Identifies and seeks to have a higher level of } \\
\text { performance than prospective internal } \\
\text { challengers. }\end{array}$ & 0 & 0.0 & 3 & 2.8 & 7 & 6.5 & 74 & 69.2 & 23 & 21.5 \\
\hline $\begin{array}{l}\text { Performance is significantly unaffected by } \\
\text { difficult, complex, or unexpected situations. }\end{array}$ & 0 & 0.0 & 3 & 2.8 & 6 & 5.6 & 61 & 57.0 & 37 & 34.6 \\
\hline
\end{tabular}


Table (5): Needs assessment related to commitment and sense of ownership (No. 107).

\begin{tabular}{|c|c|c|c|c|c|c|c|c|c|c|}
\hline \multirow[t]{2}{*}{ Description } & \multicolumn{2}{|c|}{ Remove } & \multicolumn{2}{|c|}{$\begin{array}{l}\text { Suppl. } \\
\text { Yearly }\end{array}$} & \multicolumn{2}{|c|}{$\begin{array}{c}\text { Suppl. } \\
\text { quarterly }\end{array}$} & \multicolumn{2}{|c|}{ Core } & \multicolumn{2}{|c|}{ Expert } \\
\hline & No. & $\%$ & No. & $\%$ & No. & $\%$ & No. & $\%$ & No. & $\%$ \\
\hline Aggressively capitalizes on opportunities. & 0 & 0.0 & 6 & 5.6 & 9 & 8.4 & 57 & 53.3 & 35 & 32.7 \\
\hline $\begin{array}{l}\text { eeks out the voice of the patient at all stages of } \\
\text { eatment. }\end{array}$ & 0 & 0.0 & 3 & 2.8 & 6 & 5.6 & 54 & 50.5 & 44 & 41.1 \\
\hline $\begin{array}{l}\text { Sets challenging goals beyond targets set by } \\
\text { management. }\end{array}$ & 0 & 0.0 & 3 & 2.8 & 6 & 5.6 & 58 & 54.2 & 40 & 37.4 \\
\hline $\begin{array}{l}\text { Encourages goal setting for staff members to } \\
\text { achieve professional goals. }\end{array}$ & 0 & 0.0 & 0 & 0.0 & 12 & 11.2 & 69 & 64.5 & 26 & 24.3 \\
\hline $\begin{array}{l}\text { Understands and explains the relationship between } \\
\text { organization, department, and hospital goals. }\end{array}$ & 0 & 0.0 & 0 & 0.0 & 15 & 14.0 & 73 & 68.2 & 19 & 17.8 \\
\hline $\begin{array}{l}\text { Establishes and builds trust among employees and } \\
\text { the organization. }\end{array}$ & 0 & 0.0 & 12 & 11.2 & 15 & 14.0 & 54 & 50.5 & 26 & 24.3 \\
\hline Participates in relationships based on trust. & 0 & 0.0 & 15 & 14.0 & 15 & 14.0 & 58 & 54.2 & 19 & 17.8 \\
\hline $\begin{array}{l}\text { I plan beyond the expected results required to } \\
\text { achieve. }\end{array}$ & 0 & 0.0 & 6 & 5.6 & 24 & 22.4 & 54 & 50.5 & 23 & 21.5 \\
\hline $\begin{array}{l}\text { Assumes personal responsibility for hospital } \\
\text { regardless of the outcome. }\end{array}$ & 0 & 0.0 & 6 & 5.6 & 32 & 29.9 & 54 & 50.5 & 15 & 14.0 \\
\hline $\begin{array}{l}\text { Works diligently to maintain/improve image of } \\
\text { one's professional reputation and that of his/her } \\
\text { organization. }\end{array}$ & 0 & 0.0 & 9 & 8.4 & 29 & 27.1 & 38 & 35.5 & 31 & 29.0 \\
\hline $\begin{array}{l}\text { Expects the best possible work from peers and } \\
\text { subordinates. }\end{array}$ & 0 & 0.0 & 9 & 8.4 & 23 & 21.5 & 58 & 54.2 & 17 & 15.9 \\
\hline $\begin{array}{l}\text { Reflects upon past performance and uses } \\
\text { achievements to guide future challenges. }\end{array}$ & 3 & 2.8 & 12 & 11.2 & 24 & 22.4 & 47 & 43.9 & 21 & 19.6 \\
\hline Use achievement to guide future challenges. & 0 & 0.0 & 3 & 2.8 & 27 & 25.2 & 51 & 47.7 & 26 & 24.3 \\
\hline $\begin{array}{l}\text { Seeks out and implements ethical policies from } \\
\text { legislation, professional organizations, and nursing } \\
\text { standards. }\end{array}$ & 3 & 2.8 & 3 & 2.8 & 30 & 28.0 & 60 & 56.1 & 11 & 10.3 \\
\hline Clarifies the details of goals, reduces interruptions. & 0 & 0.0 & 3 & 2.8 & 32 & 29.9 & 48 & 44.9 & 24 & 22.4 \\
\hline $\begin{array}{l}\text { Shows a long-term commitment to the ideals of the } \\
\text { organization and does not display a fickle attitude. }\end{array}$ & 3 & 2.8 & 0 & 0.0 & 37 & 34.6 & 51 & 47.7 & 16 & 15.0 \\
\hline
\end{tabular}

Table (6): Needs assessment of nurse managers related to communication, interpersonal skills, and emotional intelligence (No. 107).

\begin{tabular}{|c|c|c|c|c|c|c|c|c|c|c|}
\hline \multirow[t]{2}{*}{ Description } & \multicolumn{2}{|c|}{ Remove } & \multicolumn{2}{|c|}{$\begin{array}{l}\text { Suppl. } \\
\text { Yearly }\end{array}$} & \multicolumn{2}{|c|}{$\begin{array}{c}\text { Suppl. } \\
\text { quarterly }\end{array}$} & \multicolumn{2}{|c|}{ Core } & \multicolumn{2}{|c|}{ Expert } \\
\hline & No. & $\%$ & No. & $\%$ & No. & $\%$ & No. & $\%$ & No. & $\%$ \\
\hline $\begin{array}{l}\text { Writes high quality reports, business } \\
\text { correspondence and procedural manuals. }\end{array}$ & 0 & 0.0 & 0 & 0.0 & 33 & 30.8 & 37 & 34.6 & 37 & 34.6 \\
\hline $\begin{array}{l}\text { Drafts, re-drafts, edits, and has work reviewed by } \\
\text { others. }\end{array}$ & 0 & 0.0 & 0 & 0.0 & 33 & 30.8 & 31 & 29.0 & 43 & 40.2 \\
\hline Pays attention to memos or email. & 18 & 16.8 & 27 & 25.2 & 14 & 13.1 & 17 & 15.9 & 31 & 29.0 \\
\hline $\begin{array}{l}\text { Draws upon insights about other people's } \\
\text { perspectives to formulate a communication strategy } \\
\text { that will get others to support one's ideas. }\end{array}$ & 11 & 10.3 & 18 & 16.8 & 15 & 14.0 & 39 & 36.4 & 24 & 22.4 \\
\hline $\begin{array}{l}\text { The thought in determining the field and the right } \\
\text { time and place it into account its impact on the } \\
\text { individual and the hospital. }\end{array}$ & 1 & 0.9 & 18 & 16.8 & 26 & 24.3 & 26 & 24.3 & 36 & 33.6 \\
\hline
\end{tabular}




\begin{tabular}{|c|c|c|c|c|c|c|c|c|c|c|}
\hline \multirow[t]{2}{*}{ Description } & \multicolumn{2}{|c|}{ Remove } & \multicolumn{2}{|c|}{$\begin{array}{l}\text { Suppl. } \\
\text { Yearly }\end{array}$} & \multicolumn{2}{|c|}{$\begin{array}{c}\text { Suppl. } \\
\text { quarterly }\end{array}$} & \multicolumn{2}{|c|}{ Core } & \multicolumn{2}{|c|}{ Expert } \\
\hline & No. & $\%$ & No. & $\%$ & No. & $\%$ & No. & $\%$ & No. & $\%$ \\
\hline $\begin{array}{l}\text { 6-Understands that a message is lost on the wrong } \\
\text { people. }\end{array}$ & 4 & 3.7 & 21 & 19.6 & 15 & 14.0 & 45 & 42.1 & 22 & 20.6 \\
\hline Uses the right level of detail and language. & 15 & 14.0 & 18 & 16.8 & 8 & 7.5 & 44 & 41.1 & 22 & 20.6 \\
\hline $\begin{array}{l}\text { Controls the level and flow of information to } \\
\text { subordinates. }\end{array}$ & 0 & 0.0 & 18 & 16.8 & 7 & 6.5 & 60 & 56.1 & 22 & 20.6 \\
\hline $\begin{array}{l}\text { 9- Seeks detailed explanations and expansion of } \\
\text { ideas and concerns. }\end{array}$ & 0 & 0.0 & 21 & 19.6 & 6 & 5.6 & 55 & 51.4 & 25 & 23.4 \\
\hline $\begin{array}{l}\text { Ensures the speaker and listener are on the same } \\
\text { page. Checks for gaps in communications. }\end{array}$ & 0 & 0.0 & 0 & 0.0 & 31 & 29.0 & 65 & 60.7 & 11 & 10.3 \\
\hline Encourages team members to voice concerns. & 0 & 0.0 & 0 & 0.0 & 28 & 26.2 & 63 & 58.9 & 16 & 15.0 \\
\hline $\begin{array}{l}\text { Takes the time to really listen to staff members and } \\
\text { also explains their own feelings and comments. }\end{array}$ & 0 & 0.0 & 0 & 0.0 & 27 & 25.2 & 57 & 53.3 & 23 & 21.5 \\
\hline $\begin{array}{l}\text { Maintain report of the participants during the daily } \\
\text { work of the department }\end{array}$ & 0 & 0.0 & 3 & 2.8 & 27 & 25.2 & 58 & 54.2 & 19 & 17.8 \\
\hline $\begin{array}{l}\text { Knows how to bring out unspoken thoughts or } \\
\text { concerns. }\end{array}$ & 0 & 0.0 & 0 & 0.0 & 25 & 23.4 & 57 & 53.3 & 25 & 23.4 \\
\hline $\begin{array}{l}\text { take time to communicate with personnel and } \\
\text { interpret their emotions and comments. }\end{array}$ & 0 & 0.0 & 0 & 0.0 & 28 & 26.2 & 58 & 54.2 & 21 & 19.6 \\
\hline Understand body language and response sensitively. & 1 & 0.9 & 0 & 0.0 & 33 & 30.8 & 48 & 44.9 & 25 & 23.4 \\
\hline Makes an effort to address needs and concerns. & 1 & 0.9 & 3 & 2.8 & 24 & 22.4 & 40 & 37.4 & 39 & 36.4 \\
\hline $\begin{array}{l}\text { Maintains a professional demeanor in decision } \\
\text { making. }\end{array}$ & 1 & 0.9 & 0 & 0.0 & 30 & 28.0 & 37 & 34.6 & 39 & 36.4 \\
\hline Maintain eye contact and not interrupt. & 1 & 0.9 & 0 & 0.0 & 30 & 28.0 & 41 & 38.3 & 35 & 32.7 \\
\hline Treat others gently and politeness. & 0 & 0.0 & 0 & 0.0 & 27 & 25.2 & 40 & 37.4 & 40 & 37.4 \\
\hline Makes an effort to address needs and concerns. & 3 & 2.8 & 0 & 0.0 & 24 & 22.4 & 45 & 42.1 & 35 & 32.7 \\
\hline $\begin{array}{l}\text { Does not let personal feelings interfere with } \\
\text { evaluation of feedback. }\end{array}$ & 6 & 5.6 & 3 & 2.8 & 22 & 20.6 & 47 & 43.9 & 29 & 27.1 \\
\hline $\begin{array}{l}\text { Maintains a professional demeanor in decision } \\
\text { making. }\end{array}$ & 0 & 0.0 & 3 & 2.8 & 11 & 10.3 & 63 & 58.9 & 30 & 28.0 \\
\hline Is not timid with regard to stating "the hard things". & 0 & 0.0 & 0 & 0.0 & 15 & 14.0 & 69 & 64.5 & 23 & 21.5 \\
\hline Develops overall psychological profile of others. & 3 & 2.8 & 12 & 11.2 & 10 & 9.3 & 50 & 46.7 & 32 & 29.9 \\
\hline $\begin{array}{l}\text { Reacts to situations in an appropriate and } \\
\text { professional manner. }\end{array}$ & 6 & 5.6 & 12 & 11.2 & 19 & 17.8 & 50 & 46.7 & 20 & 18.7 \\
\hline $\begin{array}{l}\text { Has the ability to effectively communicate ideas and } \\
\text { generate the interest and support of others. }\end{array}$ & 0 & 0.0 & 13 & 12.1 & 15 & 14.0 & 51 & 47.7 & 28 & 26.2 \\
\hline $\begin{array}{l}\text { Listens carefully to choose of words and intonation } \\
\text { to translate actual meaning from literal meaning. }\end{array}$ & 0 & 0.0 & 12 & 11.2 & 15 & 14.0 & 47 & 43.9 & 33 & 30.8 \\
\hline $\begin{array}{l}\text { Ability to initiate and mediate discussion between } \\
\text { individuals with widely differing perceptions. }\end{array}$ & 0 & 0.0 & 15 & 14.0 & 9 & 8.4 & 54 & 50.5 & 29 & 27.1 \\
\hline Builds positive rapport. & 0 & 0.0 & 12 & 11.2 & 13 & 12.1 & 64 & 59.8 & 18 & 16.8 \\
\hline $\begin{array}{l}\text { Keeps in touch with key stakeholders, even after } \\
\text { the reason for interacting with them have elapsed. }\end{array}$ & 0 & 0.0 & 25 & 23.4 & 16 & 15.0 & 54 & 50.5 & 12 & 11.2 \\
\hline
\end{tabular}


Table (7): Needs assessment of nurse managers related to mission and vision (No. 107).

\begin{tabular}{|c|c|c|c|c|c|c|c|c|c|c|}
\hline \multirow{2}{*}{ Description } & \multicolumn{2}{|c|}{ Remove } & \multicolumn{2}{|c|}{$\begin{array}{l}\text { Suppl. } \\
\text { Yearly }\end{array}$} & \multicolumn{2}{|c|}{$\begin{array}{c}\text { Suppl. } \\
\text { quarterly }\end{array}$} & \multicolumn{2}{|c|}{ Core } & \multicolumn{2}{|c|}{ Expert } \\
\hline & No. & $\%$ & No. & $\%$ & No. & $\%$ & No. & $\%$ & No. & $\%$ \\
\hline $\begin{array}{l}\text { Contributes to the development of the mission and } \\
\text { vision. }\end{array}$ & 40 & 37.4 & 21 & 19.6 & 17 & 15.9 & 20 & 18.7 & 9 & 8.4 \\
\hline $\begin{array}{l}\text { Establishes credibility for the vision by } \\
\text { communicating it in the broader context of the } \\
\text { industry and marketplace within which the hospital } \\
\text { is operating. }\end{array}$ & 21 & 19.6 & 33 & 30.8 & 18 & 16.8 & 20 & 18.7 & 15 & 14.0 \\
\hline $\begin{array}{l}\text { Shares both internal and external trends and how } \\
\text { they provide the foundation for the group's } \\
\text { direction. }\end{array}$ & 12 & 11.2 & 37 & 34.6 & 29 & 27.1 & 21 & 19.6 & 8 & 7.5 \\
\hline $\begin{array}{l}\text { Sees the mission/vision in a variety of ways in order } \\
\text { to interpret it's true meaning to the organization. }\end{array}$ & 13 & 12.1 & 39 & 36.4 & 24 & 22.4 & 24 & 22.4 & 7 & 6.5 \\
\hline $\begin{array}{l}\text { Acts as though the mission and vision are part of an } \\
\text { employee's daily conduct. }\end{array}$ & 9 & 8.4 & 28 & 26.2 & 20 & 18.7 & 35 & 32.7 & 15 & 14.0 \\
\hline $\begin{array}{l}\text { Expands upon and explains critical/systems } \\
\text { thinking, value-analysis. }\end{array}$ & 6 & 5.6 & 16 & 15.0 & 15 & 14.0 & 45 & 42.1 & 25 & 23.4 \\
\hline Explain importance of strategic planning & 74 & 69.2 & 12 & 11.2 & 5 & 4.7 & 15 & 14.0 & 1 & 0.9 \\
\hline
\end{tabular}

Table (8): Needs assessment of nurse managers related to leading groups and teams (No. 107).

\section{Description}

Understands and communicates with team members to let them know that they are valued as individuals and allows them to share in the team's vision and successes. Can assess and capitalize on team strengths and work to downplay or even improve team weaknesses.

Works collaboratively, demonstrates openness, ensures conflict resolution and partners to achieve results.

Is committed to the team and the team's role in the organization.

Encourages team members to commit to the team. Seeks honest communications between team members.

Provides appropriate level of financial reward.

Empowers individuals and team members to make decisions in their areas of responsibility. Ensures that others participate and contribute. Establishes and communicates clear expectations of team members.

Act as example for the team. Allows challenges to be shared by the team. Facilitates discussion with the team to come up with collectively generated solutions.

\begin{tabular}{|c|c|c|c|c|c|c|c|c|c|c|}
\hline \multicolumn{2}{|c|}{ Remove } & \multicolumn{2}{|c|}{$\begin{array}{c}\text { Suppl. } \\
\text { Yearly }\end{array}$} & \multicolumn{2}{|l|}{ Suppl. } \\
quarterly & \multicolumn{2}{l|}{ Core } & \multicolumn{2}{l|}{ Expert } \\
\hline No. & $\%$ & No. & $\%$ & No. & $\%$ & No. & $\%$ & No. & $\%$ \\
\hline 0 & 0.0 & 0 & 0.0 & 14 & 13.1 & 47 & 43.9 & 46 & 43.0 \\
\hline 0 & 0.0 & 0 & 0.0 & 17 & 15.9 & 41 & 38.3 & 49 & 45.8 \\
\hline 0 & 0.0 & 0 & 0.0 & 19 & 17.8 & 50 & 46.7 & 38 & 35.5 \\
\hline 0 & 0.0 & 0 & 0.0 & 12 & 11.2 & 57 & 53.3 & 38 & 35.5 \\
\hline 0 & 0.0 & 0 & 0.0 & 12 & 11.2 & 62 & 57.9 & 33 & 30.8 \\
\hline 3 & 2.8 & 6 & 5.6 & 19 & 17.8 & 56 & 52.3 & 23 & 21.5 \\
\hline 0 & 0.0 & 6 & 5.6 & 21 & 19.6 & 56 & 52.3 & 24 & 22.4 \\
\hline 0 & 0.0 & 0 & 0.0 & 25 & 23.4 & 60 & 56.1 & 22 & 20.6 \\
\hline 0 & 0.0 & 3 & 2.8 & 13 & 12.1 & 75 & 70.1 & 16 & 15.0 \\
\hline 0 & 0.0 & 0 & 0.0 & 18 & 16.8 & 76 & 71.0 & 13 & 12.1 \\
\hline 0 & 0.0 & 0 & 0.0 & 16 & 15.0 & 73 & 68.2 & 18 & 16.8 \\
\hline 0 & 0.0 & 0 & 0.0 & 12 & 11.2 & 81 & 75.7 & 14 & 13.1 \\
\hline
\end{tabular}


Table (9): Needs assessment of nurse managers related to role identity, power, and politics (No. 107).

\begin{tabular}{|c|c|c|c|c|c|c|c|c|c|c|}
\hline \multirow[t]{2}{*}{ Description } & \multicolumn{2}{|c|}{ Remove } & \multicolumn{2}{|c|}{$\begin{array}{l}\text { Suppl. } \\
\text { yearly }\end{array}$} & \multicolumn{2}{|c|}{$\begin{array}{c}\text { Suppl. } \\
\text { quarterly }\end{array}$} & \multicolumn{2}{|c|}{ Core } & \multicolumn{2}{|c|}{ Expert } \\
\hline & No. & $\%$ & No. & $\%$ & No. & $\%$ & No. & $\%$ & No. & $\%$ \\
\hline $\begin{array}{l}\text { Recognizes and accepts different roles and the } \\
\text { impact of internal structures. }\end{array}$ & 0 & 0.0 & 0 & 0.0 & 9 & 8.4 & 56 & 52.3 & 42 & 39.3 \\
\hline Uses differences in positive ways. & 0 & 0.0 & 0 & 0.0 & 6 & 5.6 & 59 & 55.1 & 42 & 39.3 \\
\hline $\begin{array}{l}\text { Maneuvers so that the nurses make a positive } \\
\text { decision themselves. }\end{array}$ & 0 & 0.0 & 3 & 2.8 & 6 & 5.6 & 56 & 52.3 & 42 & 39.3 \\
\hline Tries not to force a good idea. & 6 & 5.6 & 0 & 0.0 & 3 & 2.8 & 60 & 56.1 & 38 & 35.5 \\
\hline $\begin{array}{l}\text { Strategically plans out influence approach and } \\
\text { timing based on in depth understanding of the } \\
\text { people, patients, hospital. }\end{array}$ & 1 & 0.9 & 0 & 0.0 & 5 & 4.7 & 52 & 48.6 & 49 & 45.8 \\
\hline Carefully thinks to achieve hospital goals. & 0 & 0.0 & 0 & 0.0 & 15 & 14.0 & 39 & 36.4 & 53 & 49.5 \\
\hline $\begin{array}{l}\text { Understand that achievement of mission or } \\
\text { completion of strategic decision is analogous to a } \\
\text { game. }\end{array}$ & 0 & 0.0 & 3 & 2.8 & 15 & 14.0 & 42 & 39.3 & 47 & 43.9 \\
\hline Anticipates others' responses. & 0 & 0.0 & 1 & 0.9 & 9 & 8.4 & 51 & 47.7 & 46 & 43.0 \\
\hline $\begin{array}{l}\text { Does not take no for an answer and seeks to find } \\
\text { solutions to challenges that require mutual benefit } \\
\text { for key stakeholders. }\end{array}$ & 2 & 1.9 & 6 & 5.6 & 12 & 11.2 & 49 & 45.8 & 38 & 35.5 \\
\hline Encourages win/win situations. & 0 & 0.0 & 6 & 5.6 & 6 & 5.6 & 54 & 50.5 & 41 & 38.3 \\
\hline $\begin{array}{l}\text { Resolves disputes, finds agreement on courses of } \\
\text { action, understand the advantages and } \\
\text { disadvantages of alternatives. }\end{array}$ & 0 & 0.0 & 0 & 0.0 & 9 & 8.4 & 54 & 50.5 & 44 & 41.1 \\
\hline $\begin{array}{l}\text { Comes to terms with the fact that despite the power } \\
\text { and the position of leadership, the answer may be } \\
\text { neither obvious nor easily reached. }\end{array}$ & 2 & 1.9 & 0 & 0.0 & 6 & 5.6 & 57 & 53.3 & 42 & 39.3 \\
\hline Not afraid to seek advice from subordinates. & 2 & 1.9 & 6 & 5.6 & 3 & 2.8 & 66 & 61.7 & 30 & 28.0 \\
\hline $\begin{array}{l}\text { Acknowledges that having power without } \\
\text { supportive relationships with superiors, equals, and } \\
\text { subordinates is useless. }\end{array}$ & 0 & 0.0 & 0 & 0.0 & 6 & 5.6 & 67 & 62.6 & 34 & 31.8 \\
\hline $\begin{array}{l}\text { Is willing to put one's job at risk for reasons of } \\
\text { sound principle. }\end{array}$ & 0 & 0.0 & 0 & 0.0 & 8 & 7.5 & 82 & 76.6 & 17 & 15.9 \\
\hline $\begin{array}{l}\text { Expects honesty in all business dealings. Is } \\
\text { trustworthy, and sincere in demeanor. }\end{array}$ & 3 & 2.8 & 0 & 0.0 & 6 & 5.6 & 82 & 76.6 & 16 & 15.0 \\
\hline $\begin{array}{l}\text { Behaves in a manner indicative of their role. } \\
\text { Dresses appropriate to business expectations. } \\
\text { Practices good grooming and hygiene. }\end{array}$ & 1 & 0.9 & 3 & 2.8 & 5 & 4.7 & 78 & 72.9 & 20 & 18.7 \\
\hline
\end{tabular}


Table (10): Needs assessment of nurse managers related to understanding the internal environment (No. 107).

\begin{tabular}{|c|c|c|c|c|c|c|c|c|c|c|}
\hline \multirow[t]{2}{*}{ Description } & \multicolumn{2}{|c|}{ Remove } & \multicolumn{2}{|c|}{$\begin{array}{l}\text { Suppl. } \\
\text { yearly }\end{array}$} & \multicolumn{2}{|c|}{$\begin{array}{c}\text { Suppl. } \\
\text { quarterly }\end{array}$} & \multicolumn{2}{|c|}{ Core } & \multicolumn{2}{|c|}{ Expert } \\
\hline & No. & $\%$ & No. & $\%$ & No. & $\%$ & No. & $\%$ & No. & $\%$ \\
\hline $\begin{array}{l}\text { Knows how competitors do their business and acts } \\
\text { to combat threats. }\end{array}$ & 0 & 0.0 & 3 & 2.8 & 16 & 15.0 & 56 & 52.3 & 32 & 29.9 \\
\hline $\begin{array}{l}\text { Talks regularly with finance, accounting, } \\
\text { marketing and other internal departments. }\end{array}$ & 0 & 0.0 & 3 & 2.8 & 21 & 19.6 & 48 & 44.9 & 35 & 32.7 \\
\hline $\begin{array}{l}\text { Demonstrates an ability to interact with investors } \\
\text { to provide or obtain information relevant to the } \\
\text { hospital. }\end{array}$ & 0 & 0.0 & 6 & 5.6 & 18 & 16.8 & 58 & 54.2 & 25 & 23.4 \\
\hline $\begin{array}{l}\text { Monitors news and politics in public to. Keeps up } \\
\text { to date, maintains awareness of medical trends, } \\
\text { analyzes trends, makes recommendations, } \\
\text { develops information network. }\end{array}$ & 0 & 0.0 & 3 & 2.8 & 24 & 22.4 & 53 & 49.5 & 27 & 25.2 \\
\hline Seeks to meet people, attend events. & 5 & 4.7 & 3 & 2.8 & 21 & 19.6 & 49 & 45.8 & 29 & 27.1 \\
\hline $\begin{array}{l}\text { Have professional relationships that are outside } \\
\text { direct work focus. }\end{array}$ & 3 & 2.8 & 6 & 5.6 & 16 & 15.0 & 55 & 51.4 & 27 & 25.2 \\
\hline
\end{tabular}

Table (11): Needs assessment of nurse managers related to management and delegation (No. 107).

\begin{tabular}{|c|c|c|c|c|c|c|c|c|c|c|}
\hline \multirow[t]{2}{*}{ Description } & \multicolumn{2}{|c|}{ Remove } & \multicolumn{2}{|c|}{$\begin{array}{l}\text { Suppl. } \\
\text { yearly }\end{array}$} & \multicolumn{2}{|c|}{$\begin{array}{c}\text { Suppl. } \\
\text { quarterly }\end{array}$} & \multicolumn{2}{|c|}{ Core } & \multicolumn{2}{|c|}{ Expert } \\
\hline & No. & $\%$ & No. & $\%$ & No. & $\%$ & No. & $\%$ & No. & $\%$ \\
\hline $\begin{array}{l}\text { Understands deadlines for nursing and administrative } \\
\text { tasks. }\end{array}$ & 0 & 0.0 & 1 & 0.9 & 3 & 2.8 & 74 & 69.2 & 29 & 27.1 \\
\hline $\begin{array}{l}\text { Keeps an organized schedule, and provides workers } \\
\text { with reminders for critical tasks. }\end{array}$ & 1 & 0.9 & 1 & 0.9 & 3 & 2.8 & 78 & 72.9 & 24 & 22.4 \\
\hline $\begin{array}{l}\text { Monitors the progress of complex or initiatives which } \\
\text { involve coordinating several different areas. }\end{array}$ & 0 & 0.0 & 1 & 0.9 & 9 & 8.4 & 77 & 72.0 & 20 & 18.7 \\
\hline $\begin{array}{l}\text { Assesses the overall design of projects to ensure that } \\
\text { resources are being maximized. }\end{array}$ & 5 & 4.7 & 1 & 0.9 & 6 & 5.6 & 69 & 64.5 & 26 & 24.3 \\
\hline $\begin{array}{l}\text { Makes adjustments to budgets, personnel, etc., as } \\
\text { circumstances may require. }\end{array}$ & 6 & 5.6 & 0 & 0.0 & 9 & 8.4 & 62 & 57.9 & 30 & 28.0 \\
\hline $\begin{array}{l}\text { Gives tasks to employees based on their strengths and } \\
\text { weakness. }\end{array}$ & 0 & 0.0 & 2 & 1.9 & 15 & 14.0 & 64 & 59.8 & 26 & 24.3 \\
\hline $\begin{array}{l}\text { Is capable of meeting needs by knowing and making } \\
\text { use of both the internal and external resources }\end{array}$ & 0 & 0.0 & 0 & 0.0 & 21 & 19.6 & 60 & 56.1 & 26 & 24.3 \\
\hline Understands the team's needs outweigh self's. & 0 & 0.0 & 0 & 0.0 & 9 & 8.4 & 74 & 69.2 & 24 & 22.4 \\
\hline Defends priorities as needed. & 0 & 0.0 & 0 & 0.0 & 17 & 15.9 & 69 & 64.5 & 21 & 19.6 \\
\hline $\begin{array}{l}\text { Offer protection to members of the team of the } \\
\text { maneuvers and pressure. }\end{array}$ & 0 & 0.0 & 0 & 0.0 & 18 & 16.8 & 75 & 70.1 & 14 & 13.1 \\
\hline Holds nurses responsible for their delegated work. & 0 & 0.0 & 0 & 0.0 & 15 & 14.0 & 77 & 72.0 & 15 & 14.0 \\
\hline
\end{tabular}

Table (1): Shows that (72\%) of study subjects work in the main Assiut University Hospital. The rest of the sample are distributed between pediatric university hospital and women health university hospital. The vast majority of the subject $(92.5 \%)$ are female. Their age ranged from $35-<40$ years old. $(90.7 \%)$ of them have bachelor degree of nursing and
$(81.3 \%)$ are married. Their experience ranged between $10-<20$

years. All of them never attending training related to managerial innovation.

Table (2): Showed that the core skills (69.2) are asking probing questions in order to gather a large body of information as learning needs of nurse manager. followed by $(68.2 \%)$ stated that refreshes 
core knowledge of the profession to stay sharp is the highest importance, and also (65.4) of them cited that, the skill of applying technical and professional innovations, uses knowledge of technical/ professional developments to influence the strategic direction.

Table (3): Showed that (63.6\%) from study subjects agreed that, find new solutions followed by (59.8) for understand complex problems. While the skill of apply critical thinking to solve problem was (58.9\%).

Table (4): Revealed that, core score for the following skills and this means (the highest important) for items related to energy level and motivation are (77.6\%) for look for and obtain new responsibilities, also the second skill was $(71.0 \%)$ form the participants agreed that, motivation by positive feedback and either external or internal encouragement, $(69.2 \%)$ for both understand timelines and priorities and identifies and seeks to have a higher level of performance than prospective internal challenges, while (64.4\%) was for see possesses an inner sense of obligation to takes of high value and $(61.7 \%)$ for appropriately raises the energy level in the group through example.

Table (5): Larified that about half of the study subjects agreed on most of the items as these items were core skills for them and core skills means highest important of skills and the highest percentages of this scale were core for $(68.2 \%)$ of the study subjects agreed that "understands and explains the relationship between organization, department and hospital goals" and (64.5\%) of them agreed that encourages goal setting for staff members to achieve professional goals were core skill.

Table (6): Epicted that, slightly more than half of the subjects cited the following skills (Controls the level and flow of information to subordinates, encourages team members to voice concerns, Takes the time to really listen to staff members and also explains their own feelings and comments, maintain report of the participants during the daily work of the department, Knows how to bring out unspoken thoughts or concerns, take time to communicate with personnel and interpret their emotions and comments) as highest importance.

Table (7): Howed that, the highest percent was $(42.1 \%)$ for expand upon and explains critical, system thinking, value analyses as of the most important. Followed by (32.7) of the study subject agreed that the skill of (Acts as though the mission and vision are part of an employee's daily conduct) was considered the highest important. While the least percent was $(14.0 \%)$ for explain importance of strategic planning.

Table (8): Llustrate that, about half of the study subjects agreed that the following skills had the highest importance (Works collaboratively, demonstrates openness, ensures conflict resolution and partners to achieve results, is committed to the team and the team's role in the organization, encourages team members to commit to the team. seeks honest communications between team members, Provides appropriate level of financial reward, Empowers individuals and team members to make decisions in their areas of responsibility and ensures that others participate and contribute). While the skills of (Establishes and communicates clear expectations of team members, act as example for the team, facilitates discussion with the team to come up with collectively generated solutions) were considered highest importance respectively $(70.1 \%$, $71 \%, 75.7 \%)$.

Table (9): Showed that, $(76.6 \%)$ of them stated that the skills of (Willing to put one's job at risk for reasons of sound principle and expects honesty in all business dealings. Is trustworthy and sincere in demeanor) were considered of the highest importance. Followed by $(72.9 \%)$ stated that skill of behaves in a manner indicative of their role, dresses appropriate to business expectations, practices good grooming and hygiene was of high importance.

Table (10): Larified that (54.2\%, 52.3\%- 51.4\%) agreed that the skills of (Demonstrates an ability to interact with investors to provide or obtain information relevant to the hospital, knows how competitors do their business and acts to combat threats and have professional relationships that are outside direct work focus) were respectively of the highest importance.

Table (11): Howed that, the nurse mangers agreed that the skills of (Keeps an organized schedule, and provides workers with reminders for critical tasks, Monitors the progress of complex or initiatives which involve coordinating several different areas and holds nurses responsible for their own delegated work) were respectively of the highest importance $(72.9 \%$, $72.0 \%, 72.0 \%$ ).

\section{Discussions}

Innovation is one of the most important factors for business growth. Human capital plays a significant role in the successful process of innovation Organizational change occurs when innovative ideas are implemented and translated into the everyday life of healthcare organizations, and concerns the involvement of local healthcare professional (Waweru, \& Ngugi, 2014) This study aimed to assessment of nurse managers' needs required for managerial innovation

The results of the questionnaire interview of needs assessment related to item of learning (Table 2) as a skill needed to innovative manager, showed that more than two third of the study subjects agreed that, 
it is highly important to ask probing questions in order to gather a large body of information. This was true as probing questions were asked to clarify a situation, to provide detail to an answer already given or to understand a person's feelings. The individual may provide a response, but it may be necessary to ask probing questions afterward to find out more information (Douglas, 2009) A probing question encourages a more elaborate response with supporting details, these details lead to more innovative ideas and rethinking. This is consistent with (David, 2006) who clarified that, there were many competencies for innovative manager such as asking probing questions to learn more information and gathering data.

Moreover, refreshing core knowledge of the profession to stay sharp, applying technical and professional innovations. Using knowledge of technical \ professional developments to influence strategic direction were highly important for the study subjects where two third of them showed agreement to these statements as skills needed to innovative manager. This is might be due to that generation of new ideas that require refreshing core knowledge and improvement of technical and professional status which lead to creative and innovative ideas. This was congruent with (Kasemsap, 2013 \&Stevens, 2013) who examined the nature of the core capabilities of a firm, they focusing on the process of development of technical skills and managerial systems, it requires refreshing core knowledge.

Forgoing the results of this study about searching for academic and professional article data base on people, product, and companies revealed that, one third only of the study subject cited that this skill was needed to innovative manager. From the researchers' point of view, this might be due to the absence of technology system in the hospitals, also no access to nursing journals. and there were no researches required from nurse managers to be applied and discussed. This was incongruent with (David, 2006) who had studied the competencies needed to innovative managers and his study results revealed that, to be innovative manager you should search for academic and professional articles database on people, product and companies.

Concerning finding new solutions, understanding complex problems and applying critical thinking to solve problems, Table (3) showed that, about more than half of study subjects agreed that these skills were needed to innovative manager. Employees in many jobs encounter novel, ill-defined problems, and finding creative solutions to these problems may be the critical factor that allows their organization to maintain a competitive advantage. Solving problems creatively requires extensive and effortful cognitive processing. This requirement is magnified further by the complex, ambiguous situations in which most organizational problems occur. Employees must define and construct a problem, search and retrieve problem-relevant information, generate and evaluate a diverse set of alternative solutions. Creativity necessitates that all these activities are completed effectively. It is unlikely, therefore, that creative outcomes will be realized without a large degree of support from organizations and organizational leaders. To provide this support, leaders must understand the cognitive requirements of creative problem solving (Palmon \& llies, 2004) Persing, (1999) suggested that, the managers who focus creative efforts on innovating within job tasks rather than creating new ideas lead employees to higher level of individual innovation.

Conversely, and in contradiction with this foregoing present study result, less than one third of study subjects cited that the skill of leverages and exploits utility of uncertain situation was needed to innovative manager. This might be due to that they have no power and unsupportive relationships from medical staff so, they could not exploit the utility of uncertain situation. While (Lockett, \& Thompson, 2001) who had studied about innovative managers' characteristics, suggested that innovative managers should be risk seeking and achieve respective goals by leverages and exploits the utility of uncertain situation.

As regard energy level and motivation items as a skill needed for innovative manager Table (4) revealed that more than one third of the study subjects agreed that the highest importance of the needs for innovative manager to be motivator was looking for and obtaining new responsibilities. Motivation is a key to employee creativity, motivation bolsters one's willingness to take risks and new responsibilities (voluntarily experimenting with new ideas). One's willingness to take new responsibilities is positively associated with employee creativity and innovation. Thus, it is argued that motivation serves as a mediator of various influences on an employee's innovation (Dewett, 2007). This was congruent with David, (2006) who said that innovative managers need many competencies such as looking for and obtaining new responsibilities, through either external or internal motivation.

Commitment and sense of ownership were common themes related to innovative managers. Table (5) clarified that, about half of study subjects agreed on most of the items while more than half of them cited that understanding and explaining the relationship between organization, department, and hospital goals and encouraging goal setting for staff member to 
achieve professional goals were the highest important. This is supported by Cacioppe, (2000) who reported that organizations focus on the meaningfulness of an individual's objectives and goals. Therefore, innovation manager must establish a trust culture and maintain relationships between organization goals and link those goals to the personal needs, department and the hospital where they work.

Effective communication must occur between organizational units. At every stage of the overall innovation process there are bugs, problems to be solved and new information required, which produces feedback loops. Effective feedback loops between developers and users, facilitated by management and intermediaries. Interactions among groups within the organization, cultures and orientations, all influence the innovative process (Patterson, 2003).

As regard communication, interpersonal skills, and emotional intelligence, as skills needed to innovative managers table (6) depicted that, innovative managers should control the level and flow of information to subordinates, encourage team members to voice concern, take the time to really listen to staff members and also explain their own feelings and comments, maintain report of the participants during the daily work of the department, maintains a professional demeanor in decision making, is not timid with regard to stating the hard things, ability to initiate and mediate discussion between individuals with widely differing perceptions, build positive rapport and keeps in touch with key stakeholders even after the reason for interacting with them has elapsed. From the researcher's point of view, communicating with employee helps people to know how to guess person's needs, and help personnel to express their opinions and concerns to be addressed. So, innovative manager takes time to speak to her/his employees, and shows friendliness leads to generating the employee's innovative ideas. This was consistent with (Bockova, 2010) who stated that innovation manager must have human skills as communication and motivation.

Vision and creativity are concepts which are becoming increasingly important in many sectors in today's world. Therefore, managers should do intensive efforts to convert individual creativity into organizational creativity, against a supportive background of vision and mission (Abdullah et al., 2008). Table (7) cleared that, about one third of the study subjects cited that, skill of the highest important for mission and vision (acts as though the mission and vision are part of an employee's daily conduct). This was true because the manager should exhibit visionary leadership by communicating the organization's mission and vision and encourage that mission and vision are part of a follower's daily conduct (David, 2006). Nearly half of the study subjects agreed that expand upon and critical/ system thinking, value analysis was the highest important. Slowinski (2002) cited that, the innovative manager should encourage systems thinking and value analysis in the light of organization's mission and vision when planning their strategy to diffuse innovation. This was consistent with (Abdullah et al. 2008 \& arcDressler, 2013) as they stated that people can become more effective by trying to make them understand the importance of the processes in which they are involved.

Innovation concerns those behavioral and social processes whereby individuals, groups, or organizations seek to achieve desired changes, or avoid the penalties of inaction. Innovation is therefore the introduction of new and improved ways of doing things at work. A fuller, more explicit definition of innovation is "the intentional introduction and application within a job, work team or organization of ideas, processes, products or procedures which are new to that job, work team or organization and designed to benefit the job, the work team or the organization (West, 2002).

As regard, leading groups and teams, table (8) showed that about half of the study sample agreed that the following statement was the highest important (work collaboratively, demonstrate openness, ensure conflict resolution and partner to achieve results, committed to the team and teams' role in organization, encourages team members to be committed to the team. seeks honest communications between team members, Provides appropriate level of financial reward, Empowers individuals and team members to make decisions in their areas of responsibility and ensures that others participate and contribute) and about two third of the study subjects agreed that the following statement was the highest important (establish and communicates clear expectations of team members, act as example for the team, allows challenges to be shared by the team) and two quarter of the study subjects agreed that, facilitate discussion with the team to come up with collectively generated solution was of the highest importance, this means that innovative manager should have more skills to share his/ her innovative ideas and creative ones and this was supported by (Jones, 2000 \& Fred et al., 2011) as their results revealed that when the innovation manager establish and communicates clear expectations of team members, act as example for the team, facilitates discussion with the team to come up with collectively generated solutions, once innovation has been shared 
through the strong relationship with their team, the follower should adopt innovation.

Having a good idea, product or system is often not enough to ensure the adoption and diffusion of an innovation. Using an organizational power and politics perspective, several published accounts of product and administrative innovation are analyzed. The interplay of political tactics or games are found to be present at both the observable surface level and the deep structural level of power relationships in all areas of activity - individual, group, organizational and societal (Frost \& Egri, 1980).

The needs of innovative managers related to items of power, politics and role identity, Table (9) revealed that, about half of the study subjects agreed on most of the statements while two quarter of them agreed that the following statements of needs assessment were the highest important (is willing to put one's job at risk for reasons of sound principle, expect honesty in all business dealings is trustworthy and sincere in demeanor) and one third of them agreed that the statement of behaving in a manner indicative of their role, dress appropriate to business expectations practice good grooming and hygiene was of the highest importance. This was supported by Hendry, (1989) as his research focused on how to recognize politics and its effect on innovation.

Innovative managers should have a keen awareness of their internal environment and should be equipped with comprehensive knowledge of the structure and dynamics of the hospital system and have an overview of the key cause and factors creating an innovative environment (Birken, 2015). Table (10) illustrated that, about half of the study sample cited that, understanding the internal environment considered a need for nurse managers. This may be due to that nurses' manager communicate with internal departments for many causes, interact with patients during rounds and observe the work in her department most of the time to get information relevant to hospital objectives. David (2006) stated that the main task of innovative manager should consist of managing and controlling changes in the organization based on the responses to internal and external stimuli of environment, in which the organization operates and familiarizes with a new look at the organization from the perspective of the organization. and this is supported by Hornsby et al., (2010) who said that examining the environment is major aspect to be innovative manager.

In order to effectively plan and manage hospital departments, the innovative manager should have a keen sense of managerial skills, Table (11) depicted that, two third to three quarter of study subjects stated that, all items of this needs are necessary for innovative manager. From the researchers' point of view, the nurse manager must know the management functions and utilize them. This help in the diffusion of innovative ideas. This is supported by David, (2006) who stated that, innovative manager should have competencies of management and delegation.

Summary

Nurse managers need multiple skills to be innovative, innovation managers have a lot of skills as creative, effective communication, able to work in team effectively, managing time and delegate the work effectively. And nurse manager should be creative and innovative in solving problems and managing the work effectively.

\section{Conclusion}

The results of this study revealed that, nurse managers were need different skills required for managerial innovation as the following: learning, creativity and imagination, energy and motivation, commitment and sense of ownership, communication and interpersonal skills, mission and vision, leading groups and teams, role identity and power and finally understanding of internal environment.

\section{Recommendations}

Consequently, based upon the results, organizations and managers must help first line managers (head nurses) to be innovative through:

1-Provide training program for nurse managers about innovation

- Provide training program for new concepts of nursing management

- Specialize fund to innovative ideas,

- Provide climate and environment to serve inspiration of innovative ideas

- Give reward and motivate by incentives to share innovation.

\section{References}

1. Abdullah K., Sebahat B., Selcuk B., Mario R., (2008): Vision, creativity, strategic innovation, and transformational leadership. Problems and Perspectives in management, volume 6, Issue 2

2. Abouelenein, Y., (2016): Training needs for faculty members: Towards achieving quality of University Education in the light of technological innovations. Educational Research and Reviews, 11(13), 1180-1193.

3. Alaoutinen, S., Heikkinen, K., \& Porras, J., (2012): Experiences of learning styles in an intensive collaborative course. International Journal of Technology and Design Education, 22(1), 25-49. 
4. Amodeo, M., Collins, M., \& Clay, C., (2009): Toward best practice and innovation in independent living training: Experiences from the multi-site evaluation of federally funded projects. Children and Youth Services Review, 31(2), 185-192.

5. Barkley, E., (2009): Student engagement techniques: A handbook for college faculty. John Wiley \& Sons.

6. Birken, S., Lee, S., Weiner, B., Chin, M., Chiu, M., \& Schaefer, C., (2015): From strategy to action: how top managers' support increases middle managers' commitment to innovation implementation in healthcare organizations. Health care management review, 40(2), 159.

7. Bockova, K., (2010): Innovation management and his position in company, Quality innovation prosperity XIV $\backslash 1-2$.

8. Cacioppe, R., (2000): Creating spirit at work: Re-visioning organization development and leader - Part1. Leadership \& Organization Development Journal, 21(1), 48-55

9. David, G., (2006): Forecasting a competency model for innovation leaders using a modified Delphi technique, Copyright 2008 by ProQuest Information and Learning Company.

10. Dewett T., (2007): Linking intrinsic motivation, risk taking, and employee creativity in an $R \& D$ environment R\&D Management Wiley Online Library 37, 3. Blackwell Publishing Ltd

11. Douglas, P., (2009): A guide to interview and reference checking, Vermont Department of Human Resources, Montpelier, Vermont 056203001

12. Fred, M., Hripcsak G., Vawdrey D., Bostwick S., (2011): Use of electronic clinical documentation: time spent and team interactions. J Am Med Inform Assoc 2011; 18(2): 112-117.

13. Frost, P., Egri, C., (1980): Influence of Political Action on Innovation: Part I", Leadership \& Organization Development Journal, Vol. 11 Iss: 1, pp.17-25

14. George, J., Jones, G., (2008): Understanding and managing organizational behavior. (5/e). Upper Saddle River, NJ: Pearson Prentice Hall. ISBN: 0-13-239457-X.

15. Ghallab S., (1994): Developing and Implementing an In-service Education Program on Aseptic Technique and Principals of Sterilization for Nurses Working in Surgical Departments of Assiut University Hospital, Doctorate Thesis, Assiut University, Egypt, P.16, 21, 23, 105-115.
16. Hendry, J., (1989): Barriers to excellence and politics of innovation, working paper, Carnfield School of Management.

17. Hornsby, J., Kuratko, D., Zahra, S., (2010): Middle managers' perception of the internal environment for corporate entrepreneurship: assessing a measurement scale, Leadership \& Organization Development Journal Volume 11, Issue 1

18. Irbha, M., Jyoti, S., Supran, K., (2016): Assessing personal disposition of individuals towards technology adoption, Future

19. Ilaria T., Marco F., Michele S., (2013): Overcoming the barriers to the innovations diffusion- oriented policies. The case of Li-Ion Battery for Electric Vehicles, Electronic Conference Proceeding. Individual and Organizational Creativity innovation", Journal of European Industrial Training, Vol. 34 Iss 3 pp. $270-288$

20. Jones, T., (2000): Innovating at the Edge. Oxford: Butterworth-Heinemann.

21. Kasemsap, K., (2013). The role of knowledge sharing on organisational innovation: An integrated framework. Quality Innovation: Knowledge, Theory, and Practices: Knowledge, Theory, and Practices, 247.

22. Lockett, A., \& Thompson, S., (2001): The resource-based view and economics. Journal of management, 27(6), 723-754

23. Mahmood, K., \& Ajmal Khan, M. (2007): ICT training for LIS professionals in Pakistan: A needs assessment. Program, 41(4), 418-427.

24. Marc. Dressler, (2013): Innovation management of German wineries: from activity to capacity-an explorative multi-case survey. Wine Economics and Policy2:1,19-26

25. McCawley, P., (2009): Methods for conducting an educational needs assessment. University of Idaho, 23.

26. Naswall, K., Hellgren, J., \& Sverke, M., (Eds.). (2008): The individual in the changing working life. Cambridge University Press

27. Neeraja, K., (2011): Textbook of Communication and Education Technology for Nurses. JP Medical Ltd. Published by Jaypee Brothers Medical Publishes, New Delhi, DELHI, India)

28. Nies, M., \& McEwen, M., (2011): Community/public health nursing: Promoting the health of populations(5thed.). St. Louis, MO: Elsevier Saunders.

29. O'Grady, T., (2007): The CNE as entrepreneur: Innovation leadership for a new age. Nurse Leader, 5(1), 44-47. 
30. Palmon, R., \& Illies J., (2004): Leadership and creativity: Understanding leadership from a creative problem-solving perspective Volume 15, Issue 1, February 2004, Pages 55-77

31. Patterson, F., (2003): Innovation potential indicator. Available at: www.opp.co.uk

32. Persing, D., (1999): Managing in polychronic times: Exploring individual creativity and performance in intellectually intensive venues. Journal of Managerial Psychology, 14(5), 358-373.

33. Rhoberta, J., Hally. (2006): Nurse practitioner adoption of clinical innovation. University of San Diego, Hahn School of Nursing and Health Science.

34. Seeman, N., \& Rizo, C., (2009): Communicating the health care innovation agenda to Canadians. Policy Options, 63-67.

35. Slowinski, G., Rafii, Z., Tao, J., \& Gollob, L., (2002): After the acquisition: Managing paranoid people in schizophrenic organization. Research Technology Management, 45 (3), 21 33

36. Stevens, K., (May 31, 2013): The Impact of Evidence-Based Practice in Nursing and the Next Big Ideas" OJIN: The Online Journal of Issues in Nursing Vol. 18, No. 2, Manuscript 4.

37. Sullivan E., \& Decker P., (2005): Leadership and Management In Nursing. Sixth Edition Pearson Education International Hall New Jersey. P. 300-333

38. Treasury Board of Canada Secretariat. (2011): 2010 annual report on the health of the evaluation function. Ottawa, Canada: Government of Canada. Retrieved from http:// www.tbs-sct.gc.ca/report/orp/2011/arhef-raefetbeng.asp

39. Waweru, C., \& Ngugi, K., (2014): Influence of Financial Management Practices on the Performance of Micro and Small Enterprises in Kenya. European Journal of Business Management, 1(11), 141-161.

40. West, M., (2002): Sparkling fountains or stagnant ponds: An integrative model of creativity and innovation implementation in work groups. Applied psychology, 51(3), 355387.

41. Yoder-Wise, P., (2009): Leading and managing in nursing. Elsevier Health Sciences. 